УДК 130.2

DOI https://doi.org/10.32837/apfs.v0i29.958

\author{
O. В. Федотова \\ ORCID ID: https://orcid.org/0000-0002-5404-0249 \\ кандидат філософських наук, доцент, \\ доцент кафедри права, психології та сучасних європейських мов \\ Харківського торговельно-економічного інституту \\ Київського національного торговельно-економічного університету

\begin{abstract}
A.I. Жукова
ORCID ID: https://orcid.org/0000-0002-8140-7122 кандидат філософських наук, доцент кафедри права, психології та сучасних європейських мов Харківського торговельно-економічного інституту Київського національного торговельно-економічного університету
\end{abstract}

\title{
ПРАЦЯ ТА ДОЗВІЛЛЯ В ІСТОРІОСОФСЬКІЙ ПЕРСПЕКТИВІ: ПРОБЛЕМА СПІВВІДНОШЕННЯ
}

Постановка проблеми. Постіндустріальний (або інформаційний) етап соціокультурного життя характеризується значними трансформаціями більшості компонентів буття культури, суспільства, людини. Дозвілля та праця традиційно вважаються чи не найважливішими серед сфер людської діяльності, тому саме вони займають все більший обсяг у дослідженнях як зарубіжних, так і вітчизняних науковців. Одним з аспектів проблемного поля філософських зацікавлень $€$, на наш погляд, дослідження сутнісних і ціннісних характеристик праці та дозвілля. Аналогічно тому, як свого часу технізація праці сприяла зміні просторових і часових характеристик дозвілля, так і сьогочасна «індустрія» дозвілля, зміна його смислового поля впливає на характер праці. Тому ці види діяльності доцільно проаналізувати саме через їх зіставлення. До того ж сучасна картина взаємин цих культурних складових частин істотно змінилась у порівнянні з їхніми історичними аналогами: праця втрачає ряд функцій, визначальних для людини й культури в минулому (наприклад, успішність, кар'єрне зростання, визнання), а дозвілля, навпаки, - отримуе ті, що були пов'язані з процесом праці (наприклад, самореалізація особистості).

Такий своєрідний характер взаємин основних видів людської діяльності на сучасному етапі розвитку культури й суспільства актуалізує проблему дослідження та скеровує його на пошук відповідних аргументів для аналізу джерел виникнення, процесів історичних трансформацій та уявлень про позиції праці й дозвілля в генезі суспільної свідомості: від минулого до сучасності.

Означений контекст дослідження дасть можливість зрозуміти зумовленість смислів і ролі праці й дозвілля соціокультурними обставинами, що сприятиме формуванню історичного погляду на факти й події. Історична позиція в дослідженні означених феноменів дозволить більш обгрунтовано підійти до оцінки того, що в духовних традиціях є цінного, що потрібно зберегти, а що відкинути.

Метою дослідження $є$ виявлення ціннісного аспекту праці й дозвілля в історичній еволюції в контексті їх співвідношення один 3 одним; простеження за змінами, які відбувались в змістовному полі запропонованої для розгляду структурі «фізична праця - дозвілля - праця духовна (інтелектуальна)».

Аналіз джерел. Загальновідомими є дослідження процесу формування інформаційного суспільства та його впливу на соціальне становлення людини й культури, а саме Д. Белла, Е. Гідденса, М. Кастельса, В. Келле, А. Печеї, Е. Тоффлера, У. Бека, К. Роджека, ЖЖ. Бодріяра, на які ми будемо посилатись під час аналізу нашої проблеми. Також корисно було ознайомитись із роботами, в яких розглядались деякі проблеми сучасної дозвіллєвої сфери, Ж. Фурастьє В. Пічі, Е. Соколова, Ю. Стрєльцова, В. Бочелюка. Більш близькими за тематикою нам здаються роботи К. Маркса, М. Вебера, Е. Дюркгейма, I. Джохадзе, які акцентували на праці, на професії, та дослідженнях у сфері дозвілля в Т. Веблена, Ж. Дюмазед'є, Г. Зборовського, Р. Стеббінса, Г. Орлова, використовуючи їх уже в контексті зіставлення. Найцікавішими для нас виявились роботи французького соціолога Ж. Дюмазед'є, в яких він аналізує функції дозвілля, та робота канадського вченого Р.А. Стеббінса «Вільний час: до оптимального стилю дозвілля (погляд із Канади)», в якій розв'язується проблема можливостей смислотворення дозвіллєвих практик із позиції розподілу їх на "серйозний» i «несерйозний» види. Ми вважаємо, що розглянуті дослідження дуже важливі для вивчення феномену дозвілля та їх можна використати для аналізу взаємовідносин праці й дозвілля. 
Означену проблему в різних аспектах розглядали О. Бойко, Г. Волощенко, Л. Волобуєва, Л. Помиткіна, Б. Бессонова, І. Пантелєєва. Г. Волощенко в роботі «Дозвілля між Сходом і Заходом у Середньовіччі» пропонує ретроспективу теоретико-культурних уявлень про взаємовідносини праці й дозвілля та звертає увагу на аксіологічний аспект дозвіллєвих практик. $\mathrm{y}$ психофізіологічному ключі розглядали проблему поєднання праці й відпочинку Л. Помиткіна й Б. Бессонов, які обгрунтували необхідність свідомого поєднання праці й дозвілля в житті особистості. Найбільш грунтовною роботою дослідження дозвілля в середовищі вітчизняних науковців є монографія О. Бойко «Культура дозвілля в суспільстві ризику», яка присвячена дослідженню трансформаційних процесів і перспектив розвитку культури в суспільстві ризику. Серед виокремлених аспектів дослідження феномену дозвілля авторкою означені й взаємовпливи між працею та дозвіллям в історичній генезі. Можемо погодитись із тезою О. Бойко, що поняття праці й дозвілля мають різні варіанти тлумачень, але в суб'єктивному аспекті можуть і не розрізнюватися [6, с. 52].

Попри наведені аргументи стосовно взаємовідносин праці й дозвілля, ця проблема залишається ще мало дослідженою та потребуе уваги науковців. До того ж швидкоплинність змін у культурі й соціумі XXI століття вимагає врахування нових реалій і дискурсів щодо взаємовідносин праці й дозвілля та їх змістовного наповнення.

Викладення основного матеріалу. Звернення до історії інтелектуальних європейських традицій дозволяє припустити, що дослідження понять «праця» та «дозвілля» в їх різному співвідношенні почалося з творів Платона й Арістотеля. Тому логічним буде почати розгляд історії вищезазначених понять зі звернення до концепцій світу й людини в працях відомих грецьких класиків через вибудовування тріадної схеми: «фізична праця - дозвілля - праця духовна». На таку схему нас наштовхнула робота К. Маркса «Німецька ідеологія», в якій праця розподіляється на матеріальну й духовну [14]. 3 огляду на сучасну ситуацію та означену нами проблему додати до схеми поняття «дозвілля» видається цілком слушним.

Запропонована Платоном картина світобудови $€$ єдністю двох світів: фізичного (чуттєвого) й ідеального - світу «чистих» i «справжніх» ідей, світу трансцендентального, до якого треба прагнути, щоб досягти досконалості у всіх видах буття. Шлях до такої досконалості є просуванням до істини, яка може відкритися тільки через філософське споглядання надчуттєвого світу. Розподіл праці в «Державі» визначається природними задатками людини (домінівним станом душі), тому в «Ідеальній Державі», відповідно, існують три стани: пра- вителів, воїнів і хліборобів / ремісників / купців. Сфера істини, на думку Платона, відкривається тільки особам, які отримали спеціальну освіту, тобто філософам, «кращому класу громадян» [18]. Таке сакральне обгрунтування функцій «кращого класу» наділяє їх і привілеєм - правом на дозвілля, оскільки користування цим привілеєм $€$ «правильним» і служить «благу держави», тому вони не можуть відриватися на заняття фізичною працею, тому що вона заважає «правильності» дозвілля [18]. Праця кожного стану, за Платоном, безумовно, важлива для держави, але фізична, яка грізною Еридою народжена (Гесіод), ніяк не може прирівнюватися до інтелектуальної [18].

Погляди Арістотеля на характер праці й дозвілля також зумовлені сконструйованою ним системою світоустрою. У центрі цієї картини деміург, "сам себе мислячий розум», який складається із законів вічного універсуму. Від бога-деміурга залежить все, що є в універсумі, ним визначена мета вдосконалення та шлях до досягнення вищої якості. Арістотель розуміє подібну божественну впорядкованість світу як іерархію, яка починається з бога, спускається до нижніх щаблів біологічних видів і далі - до нижчих сутностей. Природним, найкращим i найщасливішим виявляється таке життя, що насичене інтелектуальною, духовною діяльністю, присвячене спогляданню бога й тому є шляхом як до щастя, так і до істини. Арістотель, як і Платон, вважає, що саме в такому житті - вище призначення людини. Так само як і Платон, Арістотель пов'язує означений спосіб життя 3 дозвіллям: «щастя є залежним від дозвілля" [2]. Фізична праця призначена для виживання, вона - ворог дозвілля (бо заважає спогляданню), але необхідна для забезпечення життя в суспільстві. Тому порядок універсуму Арістотеля ставить хліборобів, ремісників, торговців на нижчий щабель суспільства. Дозвілля в Арістотеля, як ми бачимо, набуває ще більшої в порівнянні з Платонівською концепцією значущості, зливаючись у вимірі соціальної ролі 3 інтелектуальною працею. Тріадна схема набуває вигляду дихотомії «фізична праця - дозвілля», оскільки поняття «духовна (інтелектуальна) праця» поглинається поняттям «дозвілля», розчиняючись у ньому.

Погодимося $з$ більшістю дослідників античної культури, які вважають, що ідеї Платона й Арістотеля відбивали аристократичні цінності й у цілому поділялися більшістю представників афінської знаті. У стратифікації знарядь праці в Арістотеля раб був «знаряддям праці, яке розмовляє», на відміну від таких, що «мовчать чи мичать», отже, виносились за дужки людської норми й, на думку X. Арендт, греки прагнули вилучити рабів 3 «умов життя» [1]. Діяльністю, наближеною до норми, достойною благородної людини, були 
література й філософія. I таке поєднання благородства й відповідного до нього заняття в загальній моделі запропонованих нами відносин між фізичною, інтелектуальною, духовною працею та дозвіллям слугувало звільненню від «ненормованості» життя, сприяло можливості досягнути гармонії та наблизитися до богів. Це й був ідеал духовного шляху людини, діяльність, яка збігалася з грецьким онтологічним ідеалом, i, на думку Арістотеля, ідентифікувалась із поняттям дозвілля. Людина, звільнена від тягаря та турбот фізичної праці, отримувала від богів життя як благо. Тому поняття дозвілля наповнювалося особливим «виховним» та «освітнім» змістом, водночас воно не ототожнювалося з поняттям «ледарство» й використовувалося в практиці виховання юнаків із почесних родин [3]. Отже, поєднання інтелектуальної діяльності й дозвілля (а саме заняття політикою, філософією, наукою, літературою та освітою) в умовах класичної античної культури робить людину щасливою та самодостатньою. Л. Волобуєва відзначає, що в епоху античності дозвілля як соціальний час, як діяльність вільної людини «мислилося як прояв іманентної універсальної креативності, що сприяє самозбереженню та відтворенню сущого в процесі переходу від хаосу до порядку» [9, с. 53]. Сутність такої творчості трактувалася як виконання програми, що привнесена ззовні, з Космосу. Вільна людина діє без примусу, силою власної натури, що знаходить відбиток у волі епічних героїв переборювати долю та тим самим співвідносити себе з богами. Зміст і характер дозвілля постійно вдосконалювалися, що знаходило свої відгуки в розвитку системи освіти й усіх видів мистецтва [17]. Свята (виконання обрядів) як організована, сезонна форма загальнонародного дозвілля відіграють комунікативну, політизовану роль, є практично постійною величиною всіх етапів історії та культури, хоча їх аксіологічні й телеологічні характеристики мають особливості в кожній культурі на кожному етапі історії. Соціальну роль народних свят Платон визначив у «Законах» (II, 653 d) так: «Боги зі співчуття до людського роду, народженому для праці, встановили замість перепочинку від цієї праці божественні святкування» [18], які, на думку Платона, є регламентованою ( «асхолія») діяльністю, призначеною для «грубої та неосвіченої юрби», яку необхідно спрямовувати до понять і вимог суспільства. Істинне дозвілля ( сххоле») цілком належить приватній особі, яка віддана своїй совісті й має право ставити їі на службу одній лише мудрості.

Хоча й Платон, і Арістотель прирівнюють будьяку фізичну працю до рабської, аналіз історичних і літературних джерел античного світу дозволяє зробити висновок, що фізична не рабська праця відрізнялась від рабської рівнем свободи. Розви- ток ідеї свободи ми можемо простежити в працях філософів пізнішої доби (наприклад, в Епікура). Відомо, що розрізнювались форми дозвілля та громадської діяльності. 3 розвитком політичного устрою суспільства поступово змінюється ставлення до вільної діяльності нижчих прошарків, наприклад ремісників, до мистецтва й творчості в цілому, які згодом почали впливати на зміну уявлень про цілеспрямовану діяльність до божественного світу, а отже, до набуття нею статусу інтелектуальної, духовної.

Зміна суспільного укладу Римської імперії потребувала нових видів трудової та дозвіллєвої діяльності, стимулювала функціональну переорієнтацію деяких попередніх. У загальному плані культура розвивається в горизонтальній площині, втрачаючи вертикальні виміри, стимулюючи практицизм. Наприклад, філософ презентує себе в ролі «духівника» патриція, допомагає подолати мотив приреченості в суспільстві, що втрачає сакральні цінності. Як і в будь-якій рабовласницькій державі, праця рабів зневажалася, робота за платню також вважалась заняттям неповажним, нікчемним. Однією з ознак інтелектуальної праці як вищої за цінністю була відсутність за неї винагороди. Ця праця була винагородою сама по собі, тобто дозвіллям.

Що ж до вільної частини населення, то дослідники античної історії та культури вказують на наявність двох форм проводження часу: "справа, діло» й «дозвілля", "negotium" та “otium". Перше поняття містило війну, землеробство й управління громадою. Поняття “оtium” поєднувало в собі задоволення виконаним завданням, яке позначалося як життєво важливе, звільнення від справ, війни або суспільних обов'язків; час, який присвячувався творчості, бесіді й розмислам; насолоду красою природи й творами мистецтва, тобто ідентифікувалось із дозвіллям, але переосмислювалось у бік поняття «безтурботність» (неробство як безтурботність). Цицерон, намагаючись сформувати ідеал otium'a, характеризував такий вільний час як спокій у поєднанні з гідністю та бачив у ньому бажаний тип дозвілля для всіх розсудливих, чесних і благородних людей, але в такому арістотелівському смислі otium залишається тепер в обмеженому середовищі деяких філософів, літераторів тощо.

Г. Волощенко вважає, що Середньовіччя успадковує від римського періоду античності три види дозвілля: «божественне дозвілля як вищу діяльність, що на неї здатні лише «обрані» та яка джерельно пов' язана 3 діяльністю піфагорійців» [10]; «високе дозвілля» Арістотеля як висока моральна діяльність громадянина; "дозвілля - неробство», яке успадковується з римської культури. У своїй роботі авторка намагається з'ясувати питання, як у Середньовічній Європі відбувалося формування 
поняття «дозвілля» в оптиці трьохсферності його виходу з античності [10]. Дослідження авторкою процесу формування поняття дозвілля в епоху Середньовіччя дало підстави зробити висновок, що базовим стало його тлумачення як otium неробство.

Розмірковуючи в означеній площині оцінок Середньовічних форм дозвіллєвої проблематики, зазначимо, що рання середньовічна культура склалася в результаті синтезу романізації та варваризації та спрямовувала свій розвиток у горизонтальну площину, тобто в бік розширення бази й пониження загального культурного (інтелектуального, духовного) рівня. На середньовічному етапі європейської культури розуміння понять праці й дозвілля пов'язується християнською вертикальною теоцентричною картиною світу, в якій Бог став абсолютною цінністю, а людина почала тлумачитися як образ Божий, найвеличніша цінність після Бога. Духовна основа людини, топос будь-якої діяльності розміщувались між двома точками відліку їі життя: гріхом і порятунком. У середньовічній патристиці цінності не розмежовуються, а зливаються: з однієї сторони, - моральне, естетичне й інтелектуальне, 3 іншої, - трансцендентне й іманентне. Водночас відбувається протиставлення цінностей вищих, божественних i звичайних, мирських. На цій світоглядній позиції будуються і цінності праці й дозвілля. Праця, на відміну від їі оцінки в античності, не вважалася нікчемним заняттям, але й тут існувала своя «ієрархічна драбина», типова для Середньовіччя, - на кожному соціальному рівні тлумачилася по-різному. На думку Ф. Аквінського, «насамперед і головним чином вона повинна дати прожиток; по-друге, повинна позбавляти людину стану байдикування як джерела багатьох бід; по-третє, повинна приборкувати хіть, забиваючи плоть; по-четверте, дозволяє творити милостиню» [15]. I це стосується всіх верств населення.

Так, відповідно до створеної християнством ціннісної ієрархії, відбувся і розподіл видів праці за станами: духівництво, перший стан - ті, що моляться за всіх і тому наближені до світу трансцендентних цінностей; для них працею була молитва, тобто їхня трудова діяльність мала моральне, естетичне й інтелектуальне наповнення та виправдовувала собою дозвілля священників і монахів, але дозволялась і фізична праця в невеликій кількості для того, щоб «приборкувати хіть»; аристократія та військові, лицарство (ті, що воюють) стверджували цінність свого образу життя «творенням милостині», не накопичуючи багатства, й мали для цього дозвілля, яке можна визначити як соціально-етичний обов'язок; і третій - народ, простий люд (ті, хто працює), який має відпочинок як необхідність для відтворення фізичних сил у процесі відпрацювання гріха, тобто селяни, городяни, для яких праця розглядалась як тягар повсякденної діяльності, що забезпечував земне існування. Така праця була важкою, не приносила морального задоволення, що дозволяло тлумачити її як покарання за первородний гріх, а пізніше як відпрацювання коштом тих самих характеристик.

Отже, в руслі християнської релігійної традиції сформувалось декілька підходів щодо оцінки трудової діяльності. Вона сприймалась як життєва необхідність, як засіб покаяння, творчий процес і грунтувалась на християнському вченні про первородний гріх, покарання та порятунок. У цей період розвитку культури визначення праці й дозвілля отримали чітке поєднання 3 їхньою практичною спрямованістю. Під впливом християнського вчення дозвілля у вищому ціннісному значенні збігалося 3 «неробством» ченців і молитовною споглядальністю, молитовним просвітленням духівництва, а також позитивно оцінювало «аристократичні лінощі», які в часи Середньовіччя тлумачились як такі, що були надані Богом і тому мали на меті демонструвати важливу для християнізованої соціальної ієрархії приналежність до певної страти. Таким чином, оцінки праці й дозвілля відрізняються від античного варіанту й набувають сакрального змісту: наприклад, поняття scolh набуває значення праці на «ниві Господній», що підкреслює духовну напругу людини на шляху до вищих цінностей. Фізична праця ще радикальніше відокремлюється в аксіологічному смислі від розумової, інтелектуальної, духовної, тобто від праці духівництва й аристократії, а поняття дозвілля як «неробство», як необхідність відпочинку залишається в дихотомічних стосунках із фізичною працею нижчих верств населення, маркуючи себе як вільний від роботи час. Можемо підсумувати: дозвілля в період Середньовіччя було й необхідністю, і священнодійством одночасно, а набуття ним практичного характеру деякою мірою позбавляє його функції забезпечення суто духовної діяльності, ставить дозвілля у відокремлену в порівнянні з античністю позицію та формує схему взаємовідносин праці й дозвілля як тринітарну - «фізична праця - дозвілля - духовна праця» - з урахуванням того, що поняття дозвілля як otium - «неробство» вживається в трьох смислах відповідно до соціальної функції кожного класу: «фізична праця - дозвілля як відтворення сил, зумовлене працею», «духовна діяльність аристократів як соціальна дія - дозвілля як етичний обов'язок», «духовна діяльність духівництва - дозвілля як умова забезпечення діяльності, екзистенційна основа буття». В оцінках праці й дозвілля Фомою Аквінським на дозвілля мали право всі стани, але відповідно до культурних традицій, соціальних завдань і місця в становій ієрархії. 
Розкол католицької церкви, що відбувся на початку XVI ст., ознаменував початок нової історичної епохи, яка відрізнялася іншими уявленнями про місце людини у світі й про ті життєві цілі, які вона повинна ставити для себе. Виникає нова протестантська теологія праці, а отже й дозвілля. Насамперед йдеться про професії як шлях до порятунку, за словами Жака Ле Гоффа, про порятунок не всупереч своїй праці, а за її допомогою [15]. Відбувається подолання античного уявлення про працю як про долю нижчих станів, а також реабілітація багатьох сфер діяльності, в тому числі торгової та фінансової. М. Вебер проголошує тезу: «Праця стає самоціллю та покликанНям» [7, с. 82].

У новому історичному контексті праця сприймається як мета, поставлена перед людиною Богом, людина змінює свій статус існування та покликання, якому вона повинна слідувати, тепер не справа існує для людини, а людина для справи. Перетворюючись на працівника на «ниві Господній», кожна людина торує шлях до власного порятунку, що відповідає тезі протестантських теологів про цінності будь-якої роботи, навіть самої грубої та естетично непривабливої - в Божих очах будь-яка праця є достойною та богоугодною. Тепер на шляху до «порятунку працею» виникає новий критерій оцінки людських істот стосовно їх місця в загробному житті - дисципліна й старанність у роботі. Основна особливість протестантизму, за Вебером, виражається в реабілітації світської діяльності індивіда, в наданні їй сакрального сенсу, відмінного від гріховного бажання збагачення. Можливість порятунку через працю докорінно змінює світоглядну оцінку праці й дозвілля.

Протестантська етика з її «духом капіталізму» проголосила вищими чеснотами працьовитість i заповзятливість у досягненні матеріального добробуту й достатку, й беззаперечно засуджувала все те, що якимось чином відривало від господарської та підприємницької активності або перешкоджало їй. У цей період тріадне відношення «фізична праця - дозвілля - праця інтелектуальна (духовна)» отримує інше трактування - прямо протилежне античному, бо тепер уже дозвілля визначається як неробочий час і санкціонується працею, а не навпаки, як у Платона або Арістотеля. Відпочинок - чеснота не сама по собі, а тому, що корисний і необхідний, він виконує функцію відновлення та накопичення сил для продуктивної та комерційної діяльності.

За словами Х. Арендт, «ні в якій іншій галузі Новий час не пішов так далеко, як у революційному перетворенні праці, а саме до тієї точки, коли саме значення слова, яке споконвічно містило «біду й страждання», <...> втратило свій початковий сенс» [1]. В оцінці Мішеля Фуко підстави нової релігійної етики не дозволяють кори- стуватися дозвіллям, «неробством» як безділлям (тобто без діла), без його практичної спрямованості, користуватися таким дозвіллям людина не має права «із часів Адама» [20]. Ідея індивідуалізації та корисності праці й відпочинку поступово привела до переоцінки взаємовідносин праці й дозвілля, навіть до девальвації в культурі всенародних свят.

Так логіка Vita activa була поширена майже на всі сфери людської життєдіяльності, підпорядковуючи «прекрасне й невигідне» (bonum) «корисному й необхідному» (Untile). Дозвілля дедалі більше позбавляється статусу інтелектуальності й духовності й прив'язки до певного соціального стану, починають формуватися нові відносини з працею. Але й буття людини теж втрачає свою самоцінність, оскільки зводиться до її життєздатності як виробничої істоти.

Капіталізм на свій кшталт обмежив екзистенційну свободу людини, зробивши її цілком і повністю залежною від праці й поставивши перед вибором - працювати або померти. Для людини, що виробляє (homo faber), праця - не щастя, а важка необхідність. Вона не живе, щоб працювати, а працює, щоб жити, тобто така людина, можливо, й уявляє себе активною, вільною та незалежною, проте насправді вона не вільна й не незалежна. Homo faber працює, тому що не може не працювати, й зовсім не важливо, чи приносить це задоволення, чи є ця праця творчою, чи буденною, фізичною чи інтелектуальною [12]. Здавалося б, розвиток засобів виробництва, раціоналізація та гуманізація процесу трудової діяльності повинні були супроводжуватися стиранням (або пом'якшенням) суперечності між «сутністю» та «існуванням», за термінологією Маркса, працею та дозвіллям. Але, на думку більшості дослідників, така суперечність зберігається в суспільствах різного рівня економічного розвитку, оскільки праця як «діяльність для заробітку» продовжує залишатися чимось на зразок повинності, яка накладається на людину й зумовлює їі фізичне й соціальне буття [12].

Капіталістичне «ставлення до праці» радикально переосмислило її орієнтацію 3 моральності на практицизм: зникли питання, на які була спрямована вся людська діяльність: «добре чи погано?», «істинно чи хибно?», «прекрасно чи потворно?», натомість актуалізувалися інші: «вигідно чи невигідно?», «корисно або марно?», «прибутково або збитково?». I. Джохадзе оцінює найману працю як сучасну, більш технологічну форму рабства [12], водночас рабство як спосіб існування поширюється на всіх членів суспільства, які розрізняються лише привілеями й оплатою, - всі стають заручниками капіталістичної системи, в якій людина не живе для цілей власного щастя, а існує заради самого капіталу. 
Розуміння трудових цінностей, які відповідають капіталістичному способу організації виробництва в європейських країнах, поступово закріпилось у культурі, що сприяло зміні оцінки праці й дозвілля. Між членами тріади складається новий тип відносин: праця займає провідне становище у всіх своїх різновидах і тлумачиться як цілераціональна діяльність, а дозвілля - як другорядна щодо будь-якої праці цінність - перетворюється в його структурний підрозділ. Таким чином, формується дихотомія та знову змінюється зміст: «праця (фізична й інтелектуальна) - дозвілля (неробство, свобода від праці, вільний від роботи час)».

Історія цивілізації починається з появи вільного часу, його значення в тому, що він надає можливість людині не тільки існувати як природній істоті, а й перетворює ії̈ на істоту соціальну, культурну. К. Маркс, наприклад, рекомендував скорочення часу необхідної роботи для досягнення цілей вільної та творчої праці. Збільшення кількості вільного часу шляхом науково-технічного прогресу в структурі соціального буття задало новий вектор розвитку дозвілля у $\mathrm{XX}$ ст.: змінилася не тільки технологічна, а і його ціннісна структура, вони вступили в процес руйнації, який починається зі сфер праці, дозвілля та освіти.

У структурі трудових ресурсів зменшується частка фізичної та зростає доля розумової праці. Чисто фізична праця на стадії переходу до постіндустріального суспільства знаходиться в нижній частині спектру й поступово зникає: зі становленням суперсимволічної економіки пролетар стає когнітаристом [19], панівне становище в постіндустріальному суспільстві займають представники інтелектуальної еліти (Д. Белл) [4], «працівники знання» (П. Друкер), «когнітаріат» (Е. Тоффлер), прекаріат (Г. Стендінг). У своїх дослідженнях прекаріату Д. Новіков підкреслює, що апологія прекаріату є одним з основних напрямів індивідуалістичної пропаганди, яка на противагу колективній відповідальності за умови існування людини перекладає відповідальність за власну долю виключно на неї саму [16, с. 24].

В умовах нової соціальності інтелектуальний продукт стає товаром, оскільки праця заміщується знаннями (Е. Тоффлер, П. Друкер). Але водночас у сучасному суспільстві споживання, взаємного "обміну послугами», де людина стає більш значущою в ролі споживача, а не виробника, змінюється її ціннісний світ, мета її діяльності. «До парадоксів суспільства знань належить те, що воно відмовляється від досягнення мети пізнання - істини. У цьому суспільстві ніхто вже не вчиться, щоб знати, а навчається задля самого навчання. Адже в основі суспільства знань лежить теза, що всяке знання швидко застаріває і втрачає свою цінність» [6, с. 251]. Зміна характеру праці в постіндустріальному суспільстві продукує і нові способи їі організації: на зміну довгостроковому працевлаштуванню, що суттєво обмежує мобільність працівників i роботодавців, приходять гнучкі, короткострокові форми зайнятості. Розмежування місця роботи й житла стає необов'язковим через поширення дистанційної, проєктної зайнятості, а позаофісна робота дозволяє впровадити в робочі відносини й певні дозвільні форми. Отже, взаємопереходи від праці до дозвілля, сам характер праці (як розумової, так і фізичної) та дозвілля приводить до "споріднення» цих видів людської діяльності: дозвілля починає займати простір праці й навпаки.

Дозвілля в постіндустріальному суспільстві, так само як і праця в індустріальному, капіталізується, тобто розглядається як перспективна сфера розвитку людського капіталу. Формується «цивілізація дозвілля», в якій змінюється ставлення до ролі й функцій організацій культури: просвітницька модель змінюється так званою гедоністичною концепцією, індустрія розваг прагне скрізь і щодня відтворювати «потребу» в неробстві як у розвагах. Сумно пише Ж⿱. Бодріяр про «втрату безпосередньої, взаємної, символічної людяності в стосунках" у суспільстві споживання [5, с. 205].

До того ж сфера дозвілля тепер має тенденцію використовуватися для демонстрації «престижності» свого матеріального рівня. Згідно з концепцією Т. Веблена («Теорія дозвільного класу») цінність дозвілля в тому, що демонстративне утримання від праці (демонстративне дозвілля) стає визнаним знаком репутації та статусу [8]. В умовах сучасної культури дозвілля ще широко не усвідомлюється як можливість застосування неоплачуваних зусиль із метою задоволення творчих і духовних потреб, хоча й впливає на трансформацію умов, можливостей і переваг вибору між працею та дозвіллям. Ж . Дюмазед’є пише про те, що дозвілля в сучасному постіндустріальному суспільстві набуло самостійного, незалежного від праці статусу й служить не стільки для відновлення витрачених фізичних і духовних сил, скільки для задоволення потреби вищого рівня - самовираження, самоствердження, бажаної соціальної ідентифікації. 3 Ж. Дюмазед'є можна сперечатися стосовно того, чи настав етап «цивілізації дозвілля, чи ні, але цінність дозвілля, безумовно, зросла, якщо звернутися хоча б до такого прикладу, як феномен «дауншифтингу» (simpleliving) [13, с. 85].

Ми вже з'ясували, що наука, технології, інформація та культура в цілому підняли на соціальний п'єдестал нової економіки університети, інформаційні, наукові, культурні й медичні організації як центри зосередження теоретичного й прикладного знання, змінюючи саму сферу застосування людських здібностей. Сучасна людина може віддати перевагу духовним потребам, а не високій зарплатні (діджиталізація). 
Варто зазначити, що особлива роль у культурі постіндустріального суспільства належить освіті, оскільки вона може обслуговувати не тільки професійні види діяльності, але й дозвілля. Окремі галузі й види освіти, з одного боку, готують людей до творчих видів діяльності, з іншого, - ї можна розглядати як конструктивний зміст дозвілля, який міститься в особливостях процесу мистецтва, приготуванні їжі, ремеслах, спорті, мовних дискурсах тощо. Якщо такі види робіт здійснюються у вільний час, то вони набувають характеру дозвіллєвої діяльності, яка нікому не підпорядковується, та тому відповідають соціальним та індивідуальним цілям.

Проблема сучасної культури й суспільства в тому, щоб зв'язати роботу й дозвілля з поняттям духовності. Людина може мати вільний час, але він часто не стає простором для самореалізації, навіть коли це час роботи для додаткового заробітку. Крім того, освіта дає можливість людям зрозуміти зумовленість ідеологій роботи й дозвілля соціальними обставинами, що сприяе формуванню історичного погляду на факти й події. Отже, релевантний кожній культурі тип відносин між працею та дозвіллям як найважливішими типами людської діяльності свідчить не тільки про економічні фактори змін, а й про наповнення життя людини культурою та духовним смислом, коли дозвілля стає часом для творчості, для пошуку духовних основ буття, а не простого накопичення знань заради знань.

В епоху таких змін важливо звертатися до істоpiї: творча політика й політичні програми повинні спиратися на історично усвідомлене буття та чітке уявлення про те, який зміст слід вкладати в поняття «робота» й «дозвілля». У такому сенсі певну користь може принести знання того, як минулі ідеології все далі й далі просували людство шляхом конструювання певних способів і стилів життя. Як зазначав Е. Гуссерль, тільки історичні розмисли дозволяють усвідомити фактичний стан справ у наші дні й усвідомити неминучість як очевидний факт [11, с. 61].

Висновки. На кожному історичному етапі культури склався свій тип відносин між такими видами людської діяльності, як праця та дозвілля, в кожному культурному просторі дозвілля пов'язується з працею, існує як залежна від фізичної або розумової праці категорія. Водночас аксіологічні характеристики праці в кожній культурі визначають роль і місце дозвілля в житті людини й культури. У ході дослідження ми встановили, що запропонована для дослідження структурна тріада поступово проходить такі стадії: дихотомія «фізична праця - духовна праця (дозвілля); структурна тріада «фізична праця - дозвілля - духовна праця»; дихотомія «праця фізична й духовна дозвілля», кожна з них відповідає певному типу культури й певним стадіям її розвитку.
У сучасній соціокультурній ситуації, умови якої сприяють зближенню фізичної та розумової праці, спостерігається тенденція до зникнення опозиції між працею та дозвіллям, до взаємної підміни цих понять за функціями й змістом. Ми пропонуємо для сучасного типу відносин між працею та дозвіллям поняття, яке можна визначити як монодіалог, що може утворитися як результат діяльності нового типу.

Але це - тема для подальшого дослідження, оскільки процеси, які відбуваються в дискурсах праці й дозвілля, відбиваються на якості життя індивідів і стимулюють нові питання ціннісного наповнення культурного світу.

\section{Jimepamypa}

1. Арендт X. Vita activa, или о деятельной жизни. URL: https://ru.bookmate.com/reader/ODc Brmdg? resource=book.

2. Арістотель. Нікомахова етика. URL: http:// am.history.univ.kiev.ua/Nikomakhova_etyka.pdf.

3. Арістотель. Політика. URL: http://litopys.org.ua/ aristotle/arist.htm.

4. Белл Д. Прихід постіндустріального суспільства. Сучасна зарубіжна соиіальна філософія. Київ : Либідь, 1996. 251 с.

5. Бодрийяр Ж. Общество потребления. Его мифы и структуры / пер. с фр. Е.А. Самарской. Москва : Культурная революция. Республика, 2006. 269 с.

6. Бойко О.П. Культура дозвілля у суспільстві ризику : монографія. Суми : ДВНЗ «УАБС НБУ», 2011. $285 \mathrm{c}$.

7. Вебер М. Протестантська етика і дух капіталізму / пер. з нім. О.І. Погорілого. Київ : Наш формат, 2018. $216 \mathrm{c}$.

8. Веблен T. Теория праздного класса. URL: http://www.library.fa.ru/files/Veblen.pdf.

9. Волобуева Л.Н. Досуг в контексте философско-культурологической парадигмы. Москва : МГУКИ, 2007. $156 \mathrm{c}$.

10. Волощенко Г.Г. Досуг между Востоком и Западом в Средневековье. URL: https://agikjournal.wixsite.com/ journalcer.

11.Гуссерль Э. Кризис европейских наук и трансцендентальная феноменология. Введение в феноменологическую философию / пер. с нем. Д.В. Скляднева. Санкт-Петербург : Фонд Университет «Владимир Даль», 2004. 400 c.

12. Джохадзе И. Homo faber и будущее труда. URL: https://magazines.gorky.media/logos/2004/6/homofaber-i-budushhee-truda.html.

13.Дюмазедье Ж.Р. На пути к цивилизации досуга. Вестник Московского университета. Серия 12. Социально-политические исследования. 1993. № 1. C. $83-88$.

14. Маркс К., Энгельс Ф. Немецкая идеология. URL: http://www.uaio.ru/marx/03.htm.

15. Ле Гофф Ж. Другое Средневековье: Время, труд и культура Запада. URL: http://www.fedy-diary.ru/ zhak-le-goff-drugoe-srednevekove-vremya/.

16. Новіков Д.О. Pluralitas non est poneda sine necessiate або місце теорій прекаріату у науці 
трудового права. Науковий вісник Ужгородського національного університету. Серія «Право». 2015. Вип. 34. Т. 2. С. 22-26.

17.Пантелєєва I.А. Антична людина в контексті культури дозвілля. URL: http://pnpu.edu.ua/ua/text/ filosofski_obrii/Filosofski_obrii_23.pdf.

18. Платон. Держава. URL: http://litopys.org.ua/ plato/plat.htm.

19. Тоффлер Э. Метаморфозы власти. URL: http:// filosof.historic.ru/books/item/f00/s00/z0000261/ index.shtml.

20.Фуко М. История безумия в классическую эпоху. URL: https://booksonline.com.ua/view. php?book=46516.

\section{Анотація}

Федотова О. В., Жукова А. І. Праця та дозвілля в історіософській перспективі: проблема співвідношення. - Стаття.

Стаття спрямована на дослідження співвідношення праця-дозвілля через звернення до основних інтелектуальних традицій і трансформацій, які визначили ідейний зміст праці й дозвілля в західній цивілізації. Проілюстровано, що в історичному розгляді ці поняття розташувалися в тріадній схемі «фізична праця дозвілля - праця духовна». Досліджено сутнісні й аксіологічні характеристики праці й дозвілля, які визначаються в площині культурних інтерпретацій. Зміни в семіотиці культури є детермінантами зрушення до нових духовних пошуків, які відбиваються в соціальній діяльності кожної епохи. Так, зазначено, що в античній історії та культурі діяльність, яка збігалася з грецьким онтологічним ідеалом, ідентифікується 3 поняттям дозвілля - це є духовний шлях благородної людини. У роботі з'ясовано, що на середньовічному етапі європейської культури розуміння понять праці й дозвілля пов'язується 3 християнською теоцентричною картиною світу. Виявлено, що праця спиралась на християнське вчення про первородний гріх, покарання та порятунок. Розглянуто можливість порятунку через працю, що докорінно змінює світоглядну оцінку праці й дозвілля на початку XVI ст., якому передувала протестантська етика.

У статті проаналізовано, як капіталізм обмежив екзистенційну свободу людини, зробивши ї̈ цілком і повністю залежної від праці. Визначається, що дозвілля в постіндустріальному суспільстві, так само як і праця в індустріальному, капіталізується. Автори доходять висновку, що формується "цивілізація дозвілля», в якій просвітницька модель змінюється так званою гедоністичною концепцією. Дозвілля починає займати простір праці й навпаки. Сформовано важливу тезу, що в умовах нової соціальності інтелектуальний продукт стає товаром, оскільки праця заміщується знаннями. Таким чином, доводиться, що певна схема взаємовідносин означених видів діяльності відповідає певному типу культури на її історичному етапі.

Ключові слова: праця, дозвілля, інформаційне суспільство, homo faber, неробство, духовна діяльність, аксіологія праці, соціальна діяльність.

\section{Summary}

Fedotova O. V., Zhukova A. I. Labor and leisure in a historiosophical perspective: the problem of relationships. - Article.

The article examines the relationship between labor and leisure through references to the basic intellectual traditions and transformations that have defined the ideological content of labor and leisure in the Western civilization. It is argued that within the historical consideration these concepts are located in the triadic scheme "physical work-leisure-spiritual work". Authors analyze the essential and axiological characteristics of labor and leisure that are determined in the context of cultural interpretations and in the social activities of each era. It is noted that in the ancient history the activity that coincided with the Greek ontological ideal is identified with the concept of leisure - the spiritual path of a noble man. The article finds that within the European culture the concepts of labor and leisure are associated with the Christian theocentric concept of the world in the Medieval ages. The researches found labor to be based on the Christian doctrine of original sin, punishment, and salvation. The possibility of salvation through labor in the sense of protestant ethics was declared in the early sixteenth century.

This article analyzes how capitalism limited human existential freedom, making it completely dependent on labor. It is concluded that leisure in a post-industrial society, as well as labor in an industrial one, is capitalized. The authors conclude that a "civilization of leisure" is being formed, in which the enlightenment model is being replaced by the so-called hedonistic concept. Leisure begins to occupy the space of labor and vice versa. Indeed in the conditions of the new sociality the intellectual product becomes merchandise, because work is replaced by knowledge. Thus, it is proved that a certain pattern of relations between these activities corresponds to a certain type of culture at its historical stage.

Key words: labor, leisure, information society, homo faber, idling, spiritual activity, axiology of work, social activities. 